\title{
From melatonin to systemic Gi signalling defect: a hopeful odyssey for adolescent idiopathic scoliosis
}

\author{
Marie-Yvonne Akoume*, Isabelle Turgeon, Anita Franco, Ginette Larouche, Ginette Lacroix, Alain Moreau \\ From 7th International Conference on Conservative Management of Spinal Deformities \\ Montreal, Canada. 20-22 May 2010
}

\section{Introduction}

Adolescent idiopathic scoliosis (AIS) is a complex spinal deformity of unknown aetiology and extreme variability, occurring at least in genetically predisposed children. We previously demonstrated a differential dysfunction of melatonin signaling through Gi proteins in osteoblasts from AIS patients, leading to stratification of patients into three functional subgroups. Herein we extended our study to other cell types and various Gi-coupled receptors.

\section{Methods}

Osteoblasts, myoblasts or lymphocytes from 44 AIS patients, 42 healthy subjects and 31 asymptomatic at-risk children, were screened by cellular dielectric spectroscopy (CDS) for their response to varying concentrations of melatonin or other synthetic compounds that specifically initiate Gi-mediated signal transduction.

\section{Results}

Our data showed that dysfunction of melatonin signaling is not confined in osteoblats, and revealed that AIS patients can be stratified with any compounds that initiate Gi-mediated signaling. Specificity and sensitivity of this assay was estimated at $100 \%$, since impaired signal transduction was observed only in AIS patients. The risk of developing AIS was determined in 33\% of asymptomatic at-risk children, and was confirmed clinically several months later.

\section{Conclusions}

Gi protein dysfunction is not melatonin specific but a systemic impairment that can be regarded as a key determinant in the processes leading to AIS. Targeting this defect can serve as a diagnostic procedure and a therapeutic avenue for AIS patients and population atrisk of developing AIS. Moreover, classification of individuals by evaluating Gi-coupled receptor signaling with CDS is an advantageous procedure because it can be rapidly performed without prior knowledge of the specific mutated genes.

Published: 10 September 2010

doi:10.1186/1748-7161-5-S1-017

Cite this article as: Akoume et al:: From melatonin to systemic Gi signalling defect: a hopeful odyssey for adolescent idiopathic scoliosis. Scoliosis 2010 5(Suppl 1):017.

Submit your next manuscript to BioMed Central and take full advantage of:

- Convenient online submission

- Thorough peer review

- No space constraints or color figure charges

- Immediate publication on acceptance

- Inclusion in PubMed, CAS, Scopus and Google Scholar

- Research which is freely available for redistribution

Submit your manuscript at www.biomedcentral.com/submit 